\title{
Sensory Analysis as a Tool in Determining Customer Acceptability in Natural Mask From Red Dragon Peels (Hylocereus Polyrhizus) Flour and Kefir Flour
}

\author{
Octaverina Kecvara Pritasari ${ }^{1, *}$ Didin Respurwaning Tyas ${ }^{1}$ Nia Kusstianti ${ }^{2}$ \\ Biyan Yesi Wilujeng ${ }^{3}$ Nieke Andina ${ }^{4}$ \\ 1)Universitas Negeri Surabaya \\ ${ }^{2)}$ Universitas Negeri Surabaya \\ 3)Universitas Negeri Surabaya \\ 4) Universitas Negeri Surabaya \\ *Corresponding author. Email: octaverinakecvara@unesa.ac.id
}

\begin{abstract}
Natural facial masks are cosmetics that have minimal negative effects. The purpose of this study was to find out how acceptability of natural mask preparations with kefir flour and dragon fruit peels base ingredients. Kefir cow's milk is beneficial for the skin, so it has the potential to be used as a basic ingredient in facial masks. Another ingredient added in this research is red dragon fruit skin powder (Hylocereus polyrhizus) which contains high antioxidants. Natural mask preparation formula was made with different comparisons, namely Formula X1: 5 grams of kefir flour: 0 gram of dragon fruit skin powder, Formula X2: 5 grams of kefir flour: 1.5 grams of dragon fruit skin powder. Formula X3 is 5 grams of kefir flour: 3 grams of dragon fruit skin powder. Formula X4: 5 grams of kefir flour: 4.5 grams of dragon fruit skin powder. Evaluation of mask preparations was carried out namely the application test assessing texture, color, aroma. Then the stickiness test, shelf life test and hedonic test. Obtained the best mask preparation test results namely proportion X3. In the sticky power parameter, the highest value obtained is 3,4, which is X3 mask preparation, as well as acceptability of X3 mask preparation which is most preferred by panelists. Microbiology Test results to find out the shelf life of the mask preparation can be stored until the 7th day
\end{abstract}

Keywords: sensory analysis, dragon fruit peels, facialmask

\section{INTRODUCTION}

Erratic climatic conditions, exposure to UV light and air pollution have the potential to damage the health and beauty of the skin. Consumption of foods that do not meet nutritional standards can also interfere with skin conditions. As a preventive measure to maintain skin conditions including regular skincare and as needed. Sallika in Indarto revealed that facial skin care is carried out according to the needs of the skin, by reducing excessive make-up reducing oily food and reducing stress.

Skincare that can be done for example is using a face mask.

The face mask is the smooth powder which is used for facial application and a good herbal face mask must supply necessary nutrients to the skin and should penetrate the subcutaneous tissues to deliver the required nutrients (N Himaja, 2015). Because the function of a face mask is for skin health, improving skin condition by increasing the level of cleanliness to depth and stimulating skin cells to be more active. Himaja also added, natural masks contain many benefits that are good for the skin. This opinion is reinforced by the opinion of Himaja et al., (2015) who explained that natural face masks contain several important vitamins needed for health and skin brightness. These substances prove to be beneficial to the skin in many ways and can centralize skin conditions due to the use of modern cosmetics.

Nowdays, herbal ingredients have been highly regarded in the cosmetics industry because of their historical and traditional importance (Nilforoushzadeh, et al, 2018). Herbal cosmetics are believed to increase beauty by nourishing and improving skin health. Besides that, it is satisfying because it is free from synthetic chemicals and has 
relatively fewer side effects compared to synthetic cosmetics (Joshi, 2015). This is in line with the opinion of Tranggono (2007) in his book which explains that cosmetics can also give a negative reaction to the skin, namely surface contact with irritants to the skin caused by cosmetic preparations. Besides, natural face masks are not complicated in their use and help treat skin by increasing blood circulation on the skin. Based on all the goodness and benefits, natural masks can be used as alternative facial treatments. This is corroborated by the results of Masluhiya's research that the formulation of making natural face masks needs to be done as a choice (Masluhiya, et al., 2016).

Other natural materials that can be used as material for making natural masks in this study are kefir flour. Kefir is known as one type of probiotic milk drink derived from fermented fresh milk which uses kefir grans consisting of lactic acid bacteria and yeast including Steptalococus, Lactobacillus $\mathrm{sp}_{\text {s }}$ and yeast types which ferment lactose to lactic acid and alcohol. (Rahman et. al, 1992). According to an explanation of the substance content in kefir, it can be said that kefir is potential to be made as a cosmetic ingredient. Lactic acid, exfoliating when applied to the skin, means it can trigger the regeneration of skin cells by removing dead skin cells (Awlia, 2015). Kefir masks can be used directly or can be mixed with natural ingredients to increase the benefits for the skin. One of them is the use of red dragon fruit peels.

The peels of red dragon fruit has been seen as waste only, even though the peel of the fruit is red and shaped like the fin. according to $\mathrm{Wu}$ (2006) has many advantages. The advantages of dragon fruit skin are rich in polyphenol content as a source of natural antioxidants. It is known that the antioxidant activity of red dragon fruit skin is greater than the antioxidant activity of the meat. The statement was reinforced by the opinion of Nurliyana (2010) in her study that $1 \mathrm{mg} / \mathrm{ml}$ red dragon fruit skin was able to inhibit $83,485.03 \%$ free radicals, 37 while red dragon fruit meat was only able to inhibit free radicals of $27,451,02 \%$. In addition to the content of antioxidants, dragon fruit skin can be used as an alternative sourcecosmetic bioactivity and color extraction (Chaiwut et.al., 2012)Having known all the advantages contained in kefir and dragon fruit skin so that it is considered to have the potential to improve skin health and beauty, the purpose and objective of this study are to know how the acceptability of natural mask preparations made from kefir flour and dragon fruit peels.

\section{METHOD}

\section{1 Product}

There are four formulations for facial masks to be tested on panelists. The mask formulation was made into four different percentages of the amount of red dragon fruit peels flour and kefir flour used for protocol development and sensory evaluation.

Table1 Formulations Face mask preparations used for protocol development and sensory evaluation

\begin{tabular}{|l|c|c|}
\hline & Kefir flour & Peels of Flour Dragon Fruit \\
\hline Formula 1 & 5 gram & 0 grams \\
\hline Formula 2 & 5 gram & 1,5 grams \\
\hline Formula 3 & 5 gram & 3 grams \\
\hline Formula 4 & 5 gram & 4,5 grams \\
\hline
\end{tabular}




\section{2 Selection of Panel Members}

In this test, sensory analysis involves the evaluation of products or materials by panelists. Therefore, it is important to choose panelists based on predetermined criteria. The panelists' selection was made:Filtered to eliminate for example personal prejudice, preferences, and acceptance to ensure the purpose of evaluation and differentiation between and description of product characteristics. Panelists are trained to carry out sensory evaluation procedures repeatedly and are evaluated to ensure that their product determination is consistent. Panel members must be free from taste / odor perception disorders, color blindness, denture defects, allergies that often do not consume drugs that affect sensory function.

\subsection{Sensory Characteristics and Appropriate Vocabulary.}

Samples are presented to panelists in sequence, to avoid measurement bias. The evaluation starts with the protocol steps:

1.Appearance of each product that has been diluted with water, is evaluated in a mask bowl

2 . The test is done by applying $\pm 2 \mathrm{~g}$ traditional face mask preparation to a traditional cream mask on the cheek skin using a face. mask brush

3. Allow the mask to stand for about 15 minutes.

4. The after-feel test, an adhesion test for traditional mask preparation is done, by means of, the respondent applies it to the skin, then let it sit for 15 minutes. This time due to the consideration that facial masks should not be left on the face for more than 20 minutes, on the grounds that long sticking will actually form wrinkles, skin becomes loose and facial pores enlarged (Himaja, 2015). After that, the face mask preparations are removed using a wash cloth or small towel that was previously dipped in warm water. The stickiness test is carried out in conjunction with the basting test. After that, fill out the questionnaire form by giving a cross $(\mathrm{X})$ to the box to the right of each cream scrub preparation that states the choice in the form of a Likert Scale (1 Strongly Disagree; 2 Disagree; 3 Disagree; 4 Agree; 5 Agree; Agree) on each statement in the questionnaire.

In this test sensory activities were carried out, such as observation, smell, and touch activity in four proportions of traditional face mask preparations. Evaluation methods using sensory tests are based on Almeida's opinion, namely consumer acceptance of products, such as food and personal care products, highly dependent on sensory characteristics felt during use so that their sensory profiles can be compared directly (Almeida, 2008). Sensory analysis becomes far more important when the material that forms a product comes from nature because this plant produces and emits a lot of volatile organic compounds (Mosquera, 2018). Sensory analysis is a method that allows researchers to measure the preferences and acceptance of a product. Evaluators are asked to respond after their first impression of how they like or dislike a product. This test is carried out alternately for each formula for the preparation of traditional mask preparations. The results are obtained from sensory tests of texture, color, aroma. Students are trained where the senses can be used to examine the characteristics of cosmetic preparations. They are also trained in the definition of different descriptive terms and the proper use of vocabulary.

Table 2. Sensory Characteristic and Implementation

\begin{tabular}{|l|l|l|}
\hline Sense & Characteristic & Implementation \\
\hline Color & $\begin{array}{l}\text { The expected color of the mask is } \\
\text { enough red, due to the mixing of }\end{array}$ & $\begin{array}{l}\text { Assessment can be done } \\
\text { using the sense of sight } \\
\text { (eyes on mask products), }\end{array}$ \\
\hline
\end{tabular}




\begin{tabular}{|c|c|c|}
\hline & $\begin{array}{l}\text { red dragon fruit skin flour which is } \\
\text { red and white kefir. }\end{array}$ & \\
\hline Aroma & $\begin{array}{l}\text { red scented dragon fruit skin flour, } \\
\text { because the aroma of red dragon } \\
\text { fruit skin is very pungent }\end{array}$ & $\begin{array}{l}\text { Assessment can be done } \\
\text { by using the product } \\
\text { using the sense of smell } \\
\text { (nose) of the mask } \\
\text { product }\end{array}$ \\
\hline Smooth & expected texture is smooth. & $\begin{array}{l}\text { Assessment can be done } \\
\text { by using the senses touch } \\
\text { (skin) to the mask } \\
\text { product }\end{array}$ \\
\hline The adhesiveness & $\begin{array}{l}\text { applied to the skin feels tight and } \\
\text { tight not easy to crack when it } \\
\text { dries. }\end{array}$ & $\begin{array}{l}\text { Assessment can use the } \\
\text { sense of touch (skin) as } \\
\text { well as the sense of sight } \\
\text { (eyes) on the mask } \\
\text { product. The viscosity of } \\
\text { the mask on the skin is } \\
\text { calculated for } 15 \\
\text { minutes }\end{array}$ \\
\hline Thickness & $\begin{array}{l}\text { Expected thickness of the mask is } \\
\text { thick. }\end{array}$ & $\begin{array}{l}\text { Assesment is using the } \\
\text { senses eyesight of mask } \\
\text { products, }\end{array}$ \\
\hline $\begin{array}{l}\text { Ease of lifting the } \\
\text { mask }\end{array}$ & $\begin{array}{l}\text { mask is expected to be easily } \\
\text { lifted. }\end{array}$ & $\begin{array}{l}\text { Assessment can be done } \\
\text { by using the senses } \\
\text { (skin) for mask products. } \\
\text { Ease of appointment The } \\
\text { mask is measured when } \\
\text { the kefir mask has dried }\end{array}$ \\
\hline
\end{tabular}

\subsection{Statistical analysis}

In this study, the instrument used was the observation sheet. Systematics is carried out by observation and answers in the form of a checklist. The results are analyzed using a single ANOVA and if there are any real effects, then continue the Duncan test using the SPSS program. The aspect observed in this study was a kefir face mask that was added to the extract of the red dragon fruit peel. All three samples are submitted to the panelists at once, and then the panelists must be instructed to assess the sample from left to right. The assessment criteria are based on the number of marks ().
An evaluation of traditional face mask preparations was carried out by observing 30 panelists. The panelist chooses the one that is perceived as more intense in the specified sensory attribute. The selected panelists are trained panelists. 


\section{DISCUSSION}

\section{1 Pre-experimental test results}

The results of the pre-experimental test were made for the preparation of kefir flour masks with the addition of 1 gram of red dragon fruit peel flour, 2 grams, 3 grams, 4 grams, and 5 grams. In the pre-experiment it was found that the more red dragon fruit peel flour was added, the mask preparation became thicker. The best results of dragon fruit skin flour with a proportion of 3 grams in 5 grams of kefir flour. Furthermore, the proportion of dragon fruit skin flour will be raised and lowered to 0 grams for formula X1 (control), 1.5 grams for formula $\mathrm{X} 2,3$ grams for formula $\mathrm{X} 3$, and 4.5 grams for formula $\mathrm{X} 4$.

\subsection{Results of the Basting Test data}

\subsection{Color}

Based on the results of sensory activity the results of the observations were obtained, it is known that the color of the mask that most panelists like is on the $\mathrm{X} 3$ mask preparation because the color produced is red. The red color on the X3 mask is considered appropriate because if it is applied on the face, the color of the mask prepares to look red tends to be dark. Evaardinna (2016) states that the results obtained are red pigments derived from anthocyanins such as cyanidin-3-sophoroside and cyanidin-3-glucoside. Similarly, Wrolstad (2001) states that dragon fruit skin has the potential as a natural dye because it produces a red color produced by a pigment called anthocyanin. The color of the X3 mask is desirable because the anthocyanin content in the preparation is very good.

The temperature used for extracting dragon fruit skin powder used in this study is correct, namely 500c. According to Miryanti, in general, antioxidant compounds are damaged at temperatures of 600C - 700C (Miryanti, 2011: 22). Until the dragon fruit, skin processing is carried out at temperatures below $600 \mathrm{C}$ so that antioxidant compounds are not lost and damaged. Sudarmi (2015) added that at temperatures above $50^{\circ} \mathrm{C}$ is the temperature above the stability of anthocyanins, so some anthocyanins are degraded due to heat. In addition to anthocyanins, dragon fruit and the skin also contain lots of betaline, which is a nitrogencontaining pigment. (Harivaindaran et al., 2008

The color of the mask that the panelists don't like the most on $\mathrm{X} 1$ (control) masks is yellowish-white because there is no mixture of dragon fruit skin flour. This is because the more composition of dragon fruit skin flour the more color it will produce and the less favored by the panelists.

\section{Table 3. Mean of facial mask products}

\begin{tabular}{|c|c|c|c|c|c|c|}
\hline Product & \multicolumn{7}{|c|}{ Mean } \\
\cline { 2 - 7 } & $\begin{array}{c}\text { Color } \\
\text { (Y1) }\end{array}$ & $\begin{array}{c}\text { Arom } \\
\text { a } \\
(\mathrm{Y} 2)\end{array}$ & $\begin{array}{c}\text { Texture } \\
(\mathrm{Y} 3)\end{array}$ & $\begin{array}{c}\text { Stickiness } \\
(\mathrm{Y} 4)\end{array}$ & $\begin{array}{c}\text { Viscosit } \\
\mathrm{y} \\
(\mathrm{Y} 5)\end{array}$ & $\begin{array}{c}\text { Ease of Mask } \\
\text { Removal (Y6) }\end{array}$ \\
\hline $\mathrm{X} 1$ & 1 & 1 & 1,8 & 1,1 & 1 & 1,6 \\
\hline $\mathrm{X} 2$ & 2 & 2,4 & 2,7 & 2,5 & 2,3 & 2,9 \\
\hline $\mathrm{X} 3$ & 3,6 & 3,2 & 3,5 & 3,4 & 3,7 & 3,5 \\
\hline $\mathrm{X} 4$ & 3,3 & 3 & 2,8 & 2,8 & 3,3 & 3,3 \\
\hline
\end{tabular}




\subsubsection{Texture}

Texture indicator obtained the highest value of 3.2, namely the $\mathrm{X} 3$ mask sedian with the addition of 3 grams of dragon fruit skin flour and 5 grams of kefir flour. The texture of the resulting mask is smooth. That's because one of the processes for making dragon fruit powder and kefir flour must go through the sifting stage. The use of a filter to make $0.25 \mathrm{~mm}$ dragon fruit peel powder turns out to produce the texture that panelists like. Also, the right proportion between kefir flour and dragon fruit peel powder really impresses the right delicate taste. According Anggraeni (2012) Sifting technique is done to get the desired particle size, then there are some filter standards that are usually used, one of which is fine powder number 60). The sifter is used in making dragon fruit peel flour with $0.25 \mathrm{~mm}$ (60mesh) to produce a smooth flour texture.

\subsubsection{Viscosity}

Thick masks of dragon fruit peel flour and kefir flour are controlled by adding $15 \mathrm{ml}$ of distilled water to each mask product. The highest viscosity of mask preparations was obtained at 3.7, namely at X3 with the proportion of 3 grams of dragon fruit skin flour and 5 grams of kefir flour. The viscosity produced is when it is taken and falls into the fall slowly. Based on observations when collecting data it can be seen that the most preferred facial mask preparations are X3 mask preparations with the addition of 3 grams of dragon fruit skin flour and 5 grams of kefir flour when the mask is

\subsubsection{Ease of Mask Removal}

The adhesion parameters obtained from the highest value were 3.4, namely in the preparation of mask X3 with the addition of 3 grams of dragon fruit skin powder and 5 grams of kefir flour. The resulting stickiness is well attached to the skin, feels tight, and is not easily cracked, calculated for 15 minutes after applying the mask. The ease of lifting the mask obtained by the highest value of 3.5 is on taken and massaged down slowly, while the X4 mask product with an additional 4, 5 grams of dragon fruit skin flour and 5 grams of kefir flour look very thick because when the mask preparation product is taken and dropped so it does not fall, X1 mask product with a proportion of 0 grams of dragon fruit flour and 5 grams of kefir flour looks very runny because when the mask preparation taken and dropped immediately fall. It can be concluded that the more addition of dragon fruit peel flour and kefir flour will cause the product to be thicker and solid so it is not in accordance with the thickness expected.

\subsubsection{Aroma}

One element that affects the acceptance of cosmetics is the aroma. In scents, the mask formula most liked by panelists is on X3 masks because of the aroma produced by aromatic dragon fruit. The aroma that was most disliked by the panelists was the aroma of the mask X1 due to the absence of a mixture of dragon fruit skin flour, so the mask only smelled of kefir flour.

In this study the temperature used to dry the dragon fruit skin is 500C. The aroma that is smelled on the mask is the aroma of dragon fruit skin. The aroma is greatly affected due to temperature and drying time. This is confirmed by the opinion of Purnomo (2016). The best temperature for drying is $400 \mathrm{C}$. So that a strong aroma is produced, when the temperature is increased to 500C the aroma becomes weak. This decrease is caused by warming which decreases the level of anthocyanin in the skin of dragon fruit.

$\mathrm{X} 3$ with the addition of 3 grams of dragon fruit skin powder and 5 grams of kefir flour.

The stickiness of the mask that can stick well to the skin but is easily cleaned which underlies the reason the panelist chooses this preparation. A good mask should be able to stick well, as the characteristics of a face mask according to the hairstyle that can dry out, can be applied (attached) to the skin so that the skin feels tight afterward. Another thing is the ease of lifting the mask produced which is after the mask dries can be 
rinsed with water easily. While the $\mathrm{X} 4$ mask is quite preferred by the panelists because the attachment is quite good, it feels tight and not easily cracked, but as of 45 minutes since it was app

\subsubsection{Hedonic Test Results}

The average value of panelist preferences based on the sensor test of 30 panelists it can be seen that the average value of panelists' preference at $\mathrm{X} 1$ is 1.3 , the average at $\mathrm{X} 2$ is 3.0 , the average at $\mathrm{X} 3$ is 3.3 , and the average at $\mathrm{X} 4$ is 2,4 . The highest value is the addition of 3 grams of red dragon fruit skin flour and 5 grams of kefir flour, and the lowest value is the addition of 0 grams of red dragon fruit skin flour and 5 grams of kefir flour. The following are the results of the analysis of a single anava statistical test on the average value of the finished face mask, which is shown as follows: that the average value panelists' preference at $X 1$ is 1.3 , the average at $\mathrm{X} 2$ is 3.0 , the average at $\mathrm{X} 3$ is 3.3 , and the average at $\mathrm{X} 4$ is 2.4 . The highest value is the addition of 3 grams of red dragon fruit skin flour and 5 grams of kefir flour, and the lowest value is the addition of 0 grams of red dragon fruit skin flour and 5 grams of kefir flour. Following are the results of a single anava statistical test analysis on the average value of the finished face mask, which is shown as follows:

Table 4 Anava test Single Preferred Panelist face Mask preparation

\begin{tabular}{|c|c|c|c|c|c|}
\hline & Sum of Squares & $\mathrm{df}$ & $\begin{array}{c}\text { Mean } \\
\text { Square }\end{array}$ & $\mathrm{F}$ & Sig \\
\hline Between & & & & & \\
\hline & 47.014 & 3 & 15.671 & 17.652 & .000 \\
\hline Groups & & & & & \\
\hline Within & & & & & \\
\hline & 102.986 & 116 & 888 & & \\
\hline Groups & & & & & \\
\hline Total & 150.000 & & & & \\
\hline
\end{tabular}

The results of a single anava test on the addition of red dragon fruit peel flour to the panelists' preference for the mask, were shown as much as 17,652 with $\mathrm{P}=0,000, \mathrm{P}<(0,000<0.05)$. So it can be interpreted that there is an effect of the addition of red dragon fruit skin flour to the panelists' preference for facial masks for anti-aging skin. The results of the analysis of a single anava statistical test have been carried out, then proceed with the Duncan test. Duncan's further test results showed that there were differences in the average comparison of $\mathrm{X} 3$ with other comparisons (X4, X2, $\mathrm{X} 1$ ). The average ease of lifting a mask that shows the highest value is $\mathrm{X} 3$ with comparison (3 grams of dragon fruit skin flour and 5 grams of kefir flour with a value of 3.0278 . Average value The panelist's preference for the result of being the highest mask of dragon fruit peel flour and kefir flour was obtained in X3 mask with the addition of 3 grams of nag fruit skin flour and 5 grams of kefir flour. However, because the average values of X3, $\mathrm{X} 2$ and $\mathrm{X} 4$ are in the same subset which means there is no significant difference.

\section{CONCLUSION}

After finding out the results of the research and discussion of the results, it can be concluded that: the results of the best mask preparation test on the proportion of X3. The adhesion parameters obtained from the highest value were 3.4, namely in the preparation of X3 masks, as well as acceptability of the $\mathrm{X} 3$ mask preparations the 
panelists preferred. The results of microbiological tests on these products stated to be stored until the 7th day.

\section{REFERENCES}

[1] Almeida, I. F.; Gaio, A. R.; Bahia, M. F., Hedonic And Descriptive Skinfeel Analysis Of Two Oleogels: Comparison With Other Topical Formulations. Journal of Sensory Studies (2008) $23,92-113$.

[2] Phanuphong Chaiwut, Atchara O-ki-la, Irin Phuttisatien, Nont Thitilertdecha, Punyawatt Pintathong, extraction and stability of cosmetic bioactive compounds From dragon fruit peel, 1st Mae Fah Luang University International Conference 2012

[3] Evaardinna, Ian Yulianti, Masturi. Extraction of Dragon Fruit as a Natural Coloring Substance in Batik Fabrics Proceedings of the HFI Jateng \& DIY Scientific Meeting, Salatiga 28 May 2016 ISSN: 0853-0823Himaja, Ashok kumar A, Bhart kumar B, 2015; Preparation and Evaluation of Poly Herbal Fruit Face Mask, Journal of Research in Pharmaceutical Science Volume 2 Issue 11 (2015) pp: 07-13 ISSN(Online) : 23472995

[4] Himaja, Ashok kumar A, Bhart kumar B, 2015; Preparation and Evaluation of Poly Herbal Fruit Face Mask, Journal of Research in Pharmaceutical Science Volume 2 Issue 11 (2015) pp: 07-13 ISSN(Online) : 2347-2995

[5] Ashok kumar A, Bhart kumar B, 2015; Preparation and Evaluation of Poly Herbal Fruit Face Mask, Journal of Research in Pharmaceutical Science Volume 2 Issue 11 (2015) pp: 07-13 ISSN(Online) : 2347-2995

[6] Harivaindaran KV, Rebecca OPS, Chandran S. (2008) Study of optimal temperature, $\mathrm{pH}$ and stability of dragon fruit (Hylocereus polyrhizus) peel for use as potential natural colorant. Pak J Biol Sci. 11: 2259-2263.

[7] Indarto As, 2015. Phenomenology Study of Knowledge and Caring for Traditional Beauty in Career Women Integrated Health Sciences Journal, Volume 4, Number 1, May 2015, p. 5258

[8] Joshi Laxmi, Harshal A Pawar, 2015. Herbal Cosmetics And Cosmeceuticals : An Overview. Nat Prod Chem Res 3: 170. doi:10.4172/2329-6836.1000170, Open Acces

[9] Kustanti, Herni et al. 2008. Skin Beauty Volume 2 Smk. Jakarta: Directorate of Vocational Middle School Development, Directorate General of Primary and Secondary Education Management

[10] Masluhiya Swaidatul, Widodo2, Sri Widyarti, 2016. Natural mask formulations made from bengkoang and black cumin to reduce wrinkles on the facial skin. Care Journal Vol. 4, No.2, 2016

[11] Mosquera Tayupanta TDLA, Espadero M, Mancheno M, et al. Sensory analysis of cosmetic formulations made with essential oils of Aristeguietia glutinosa (matico) and Ocotea quixos (ishpingo). Int J Phytocos Nat Ingred. 2018;5:5. doi:10.15171/ijpni.2018.05.

[12] Nilforoushzadeh Mohamad Ali, Amirkhani Mohamad Amir, Zarrintaj Payam, Moghaddam, Mehrabi, Alavi, Sisakht Mahsa Mollapour, 2018. Skin care and rejuvenation by cosmeceuticals facial mask, J Cosmet Dermatol. 2018;00:1-10. https://doi.org/10.1111/jocd.12730

[13] Sudarmi Sri, Purwo Subagyoa, Anna Susantia, Anggun Sri Wahyningsiha, 2015. Simple Anthocyanon Extraction from Dragon Fruit Skin (Hylocereus polyrhizus) as Natural Coloring. Exergy, Vol XII, No. . ISSN: 1410-394X 
[14] Wrolstad, R. E. and Giusti, M. M., 2001, Characterization and Measurement of Anthocyanin by UV-Visible Spectroscopy:

Current Protocols in Food Analytical Chemistry, John Wiley and Son, New York

[15] Wu, L. C., Hsu, H. W., Chenn, Y., Chiu, C. C., and Ho, Y. i., 2006, Antioxidant and Antiproliferative Activities of Red Pitaya, Food Chemistry Volume, 95: 319-327

[16] Tranggono, Retno Iswari and Latifah, Fatma. 2007. Cosmetic Science Handbook. Jakarta: PT. Gramedia Library. Pg. 46 